\title{
Kompres Air Hangat dalam Mengurangi Nyeri Persalinan Kala I
}

\author{
Marlynda Happy Nurmalita Sari ${ }^{1}$, Anis Alina Ramadhani ${ }^{2}$ \\ Email: marlyndasari89@gmail.com \\ Poltekkes Kemenkes Semarang ${ }^{1}$, Akademi Kebidanan Pelita Ilmu ${ }^{2}$, Indonesia \\ Jl. Tirto Agung, Pedalangan, Kec. Banyumanik, Kota Semarang, Jawa Tengah ${ }^{1}$; \\ Jl. BojongsariRaya No. 34, Bojongsari, Depok, Jawa Barat ${ }^{2}$
}

\begin{abstract}
Abstrak
Setiap ibu memiliki prespektif intensitas dan tingkat nyeri yang berbeda selama persalinan. Nyeri paling hebat terjadi pada akhir kala I ketika pembukaan serviks dan kekuatan kontraksi uterus mencapai maksimal. Nyeri persalinan menyebabkan perasaan tidak nyaman selama proses persalinan. Ada banyak cara untuk mengatasi rasa sakit, tetapi cara yang paling efektif belum ditemukan. Tujuan penelitian adalah menilai efektifitas kompres air hangat dalam mengatasi nyeri pada persalinan kala I. Desain penelitian dengan quasi eksperimen. Sampel penelitian ini adalah 28 ibu bersalin pada kala I fase aktif Penelitian dilakukan dengan cara melakukan kompres air hangat di punggung ibu selama 20 menit dengan mengukur skala nyeri menggunakan FPRS (Face Pain Rating Scale). Hasil penelitian menunjukkan bahwa ibu yang memasuki persalinan kala I fase aktif memiliki rasa sakit dengan rata-rata 3,28 lebih tinggi dibandingkan ibu setelah dilakukan kompres air hangat dengan rata-rata 1,54. Sedangkan hasil analisis T-test dependen yaitu P-value 0,0001 (P $<0,05)$. Sehingga ada perbedaan yang signifikan nyeri pada ibu yang memasuki persalinan kala I fase aktif sebelum diberikan kompres air hangat dibandingkan setelah diberikan kompres air hangat.
\end{abstract}

Kata Kunci: nyeri kala I; kompres air hangat; ibu bersalin.

\begin{abstract}
Every prespective mother has different intensity and level of pain during a labor. The greatest pain happens in the end of the first phase on servix opening, contraction and maximum uterus. Labor pain causes an uncomfortable feeling during labor process. There are many ways to resolve the pain, but the most effective way have not found yet. The purpose of this research is to measure the warm water compresses efectivity in resolving labor pain on the first phase. Design research with quasi experiment. The sample of this research are 28 giving birth mothers on the first active phase. The study was conducted by compressing warm water on the mother's back for 20 minutes by measuring pain scale. The results showed that mothers who entered labor in the first active phase had pain with a mean of 3.28 higher than mothers after warm water compresses with a mean of 1.54. The results of the dependent $\mathrm{T}$-test analysis is $\mathrm{P}$-value $0.0001(\mathrm{P}<0.05)$. There is a significant difference in pain of mothers entering labor on the first active phase before being given warm water compresses than after being given warm water compresses.
\end{abstract}

Keywords: the pain of first phase; warm water compresses; giving birth mother.

\section{Pendahuluan}

Persalinan merupakan proses fisiologis yang dialami oleh setiap wanita. Proses persalinan dimulai dengan fase pembukaan dan dilatasi serviks yang terjadi akibat adanya frekuensi, durasi, dan kekuatan yang teratur pada kontraksi uterus dilanjutkan dengan pengeluaran hasil konsepsi yaitu janin dan plasenta. ${ }^{(1)}$ Pada saat fase pembukaan (kala I) yaitu fase laten dan fase aktif ditandai dengan adanya kontraksi ibu yang semakin lama semakin teratur, sering serta akan terasa semakin nyeri. ${ }^{(2)}$ 
Jurnal Kebidanan Harapan Ibu Pekalongan

Nyeri persalinan merupakan perasaan yang tidak menyenangkan yang terjadi selama proses persalinan. Rasa nyeri karena kontraksi uterus pada saat persalinan mengakibatkan peningkatan aktifitas sistem saraf simpatis, perubahan tekanan darah, denyut jantung, pernafasan. Hal ini apabila tidak segera diatasi maka akan meningkatkan rasa khawatir, tegang, takut dan stress. Selain itu nyeri pada ibu bersalin juga menyebabkan meningkatnya kadar katekolamin atau hormon stres seperti epinefrin dan kortisol. Peningkatan kadar katekolamin atau hormon stres dapat mengurangi kemampuan tubuh ibu untuk menahan rasa nyeri. ${ }^{(3)}$

Ada berbagai cara untuk mengurangi rasa nyeri persalinan secara medis dan non medis. Cara mengurangi nyeri persalinan secara medis sudah umum digunakan di RS diantaranya dengan pemberian obat-obat analgesia yang disuntikkan melalui infus intravena, melalui inhalasi saluran pernapasan, atau dengan memblokade saraf yang menghantarkan rasa sakit. ${ }^{(4)}$ Banyak teknik baru ditemukan dalam menanggulangi nyeri secara non medis tetapi metode yang sempurna untuk mengurangi nyeri pada kelahiran sampai sekarang belum diperoleh. Salah satu cara untuk mengurangi rasa nyeri persalinan secara non medis yaitu massage atau pijat atau massage effleurage. Pijat secara lembut membantu ibu merasa lebih segar, rileks, nyaman selama persalinan dan membuat ibu merasa lebih dekat dengan orang yang merawatnya sehingga menjadi sumber kekuatan saat ibu sakit, lelah atau takut. ${ }^{(5)}$
Selain itu, penghirupan aromaterapi lavender dapat mengurangi nyeri persalinan pada primigravida kala I fase aktif. Subjek penelitian yang mengalami nyeri hebat dan nyeri berat, sesudah penghirupan aromaterapi lavender menjadi nyeri berat dan nyeri sedang. ${ }^{(6)}$

Nyeri yang hebat saat persalinan memungkinkan para ibu cenderung memilih cara yang paling mudah, murah dan cepat untuk menghilangkan rasa nyeri saat persalinan, salah satunya adalah kompres hangat. (Akbarzadeh et al. 2017) $^{(7)}$

Para bidan melakukan kompres hangat karena dianggap sebagai tindakan yang tepat untuk meredakan nyeri, dan pada beberapa wanita yang akan melahirkan diketahui bahwa penggunaan kompres hangat secara bergantian mampu memberikan rasa nyaman. ${ }^{(8)}$ Adapun tujuan dari penelitian ini adalah untuk mengetahui efektivitas penggunaan kompres air hangat untuk mengurangi nyeri persalinan kala I.

\section{Metode Penelitian}

Penelitian ini adalah penelitian analitik quasi eksperimen dengan desain one group pretest posttest. Desain dengan mengukur skala nyeri awal sebelum diberikan perlakuan dan mengukur skala nyeri setelah diberikan perlakuan kompres air hangat yang benar. Penelitian ini dilaksanakan pada Maret sampai April 2018 di RB M. Cipayung, Ciputat, Tangerang Selatan. Populasi penelitian adalah seluruh ibu yang melahirkan berjumlah 56 orang di RB M, Cipayung, Ciputat, Tangerang Selatan dengan jumlah sampel sebanyak 28 ibu melahirkan. 
Jurnal Kebidanan Harapan Ibu Pekalongan

Pengambilan sampel menggunakan teknik accidental sampling yaitu peneliti mengambil sampel yang kebetulan ditemui pada saat itu. Pengumpulan data penelitian dilakukan selama \pm 1 bulan. Sebelum melakukan penelitian pada responden, peneliti menjelaskan intervensi yang akan dilakukan dan peneliti melakukan anamnesa terkait data identitas responden. Peneliti mengobservasi intensitas nyeri dengan FPRS (Face Pain Rating Scale) yang dialami responden pada kala I fase aktif sebelum dilakukan tindakan kompres air hangat, kemudian peneliti menjelaskan, memberi contoh dan mengajarkan kompres air hangat kepada keluarga/ suami. Peneliti mengarahkan keluarga/ suami responden untuk melakukan kompres air hangat yang telah diajarkan selama \pm 20 menit pada kala I fase aktif. Peneliti mengkaji intensitas nyeri yang dirasakan responden setelah melakukan kompres air hangat dan data yang diperoleh didokumentasikan pada lembar observasi. Analisis data secara univariat bertujuan untuk menjelaskan atau mendeskripsikan karakteristik setiap variabel penelitian dengan dianalisis dalam bentuk nilai distribusi frekuensi. Analisis bivariat menggunakan uji T-Test Dependen. Penyajian data penelitian ini dalam bentuk tabel yang kemudian dijelaskan dalam bentuk narasi.

\section{Hasil dan Pembahasan}

Berdasarkan dari hasil pengolahan data baik secara univariat maupun bivariat maka dapat dilihat pada tabel penyajian analisis data. Untuk melihat gambaran distribusi responden berdasarkan umur, paritas, dan pendidikan maka dapat dilihat pada tabel berikut ini:

Tabel 1. Karakteristik Responden di RB M.

\begin{tabular}{lcc}
\hline \multicolumn{1}{c}{ Kar akteristik } & Frekuensi & Pr esentase \\
\hline Usia & 7 & 25 \\
$<20$ atau $>35$ & 21 & 75 \\
$20-35$ & & \\
Paritas & 12 & 42,9 \\
Primigravida & 16 & 57,1 \\
Multigravida & & 42,9 \\
Pendidikan & 12 & 57,1 \\
Rendah & 16 & $\mathbf{1 0 0}$ \\
Tinggi & $\mathbf{2 8}$ & \\
Total & &
\end{tabular}

Tabel 1. Menunjukkan sebagian besar responden berusia antara 20-35 tahun yaitu sebanyak 21 orang $(75 \%)$, dan responden terbanyak dengan paritas multigravida yaitu sebanyak 16 orang $(57,1 \%)$ dengan tingkat pendidikan responden terbanyak adalah pendidikan tinggi yaitu 16 orang $(57,1 \%)$.
Usia yang dianggap aman dan ideal untuk menjalani kehamilan dan persalinan yaitu usia 20-35 tahun. Ibu yang berusia 20-35 tahun secara fisik dan psikologis sudah siap dalam mengahadapi kehamilan maupun persalinan. Kesuburan seorang ibu juga dipengaruhi oleh usia sehingga pasangan berusia lanjut membutuhkan waktu lebih lama untuk dapat 
Jurnal Kebidanan Harapan Ibu Pekalongan

mengandung. Wanita hamil kurang dari 20 tahun dapat merugikan kesehatan ibu maupun perkembangan dan pertumbuhan janin karena belum matangnya alat reproduksi untuk hamil. Kurun waktu reproduksi sehat antara 2035 tahun. $^{(9)}$

Pada ibu primigravida umumnya merasa cemas dan takut menghadapi persalinan. Stres atau rasa takut secara fisiologis dapat menyebabkan kontraksi uterus menjadi terasa semakin nyeri. Jika ibu inpartu dalam kondisi stress maka tubuh merangsang untuk mengeluarkan hormon stressor yaitu hormon Katekolamin dan hormon Adrenalin. Apabila katekolamin ini dilepaskan dalam konsentrasi tinggi maka uterus menjadi semakin tegang sehingga aliran darah dan oksigen ke dalam otot-otot uterus berkurang karena arteri mengecil dan menyempit akibatnya adalah rasa nyeri yang tak tertahankan. Sedangkan ibu multigravida sudah pernah melahirkan sehingga sudah punya pengalaman nyeri saat melahirkan. Ibu yang sudah mempunyai pengalaman melahirkan akan mampu merespon rasa nyeri tersebut. Ibu yang melahirkan dalam keadaan rileks, semua lapisan otot dalam rahim akan bekerja sama secara harmonis sehingga persalinan akan berjalan lancar, mudah dan nyaman. ${ }^{(10)}$

Pendidikan akan berpengaruh terhadap penerimaan respon seseorang yang datang dari luar. Semakin tinggi tingkat pendidikan seseorang maka semakin banyak bahan, materi, dan pengetahuan yang dapat diterima dan dimiliki untuk mencapai perubahan tingkat laku yang baik. ${ }^{(11)}$

Tabel 2. Skala Nyeri Sebelum dan Sesudah Penerapan Kompres Air Hangat dalam Mengurangi Nyeri Persalinan Kala I Fase Aktif

\begin{tabular}{lcccc} 
Skala Nyer i (Face Pain Rating & \multicolumn{2}{c}{ Sebelum } & \multicolumn{2}{c}{ Sesudah } \\
\cline { 2 - 5 } \multicolumn{1}{c}{ Scale) } & F & P (\%) & F & P (\%) \\
\hline No hurts (0) & 0 & 0 & 0 & 0 \\
Hurts little bit (1) & 0 & 0 & 16 & 57,2 \\
Hurts little more (2) & 0 & 0 & 9 & 32,1 \\
Hurts even more (3) & 12 & 42,9 & 3 & 10,7 \\
Hurts whole lot (4) & 9 & 32,1 & 0 & 0 \\
Hurts worst (5) & 7 & 25 & 0 & 0 \\
Total & $\mathbf{2 8}$ & $\mathbf{1 0 0}$ & $\mathbf{2 8}$ & $\mathbf{1 0 0}$ \\
\hline
\end{tabular}

Berdasarkan tabel 2. Diketahui bahwa sebelum melakukan kompres air hangat pada persalinan kala I fase aktif responden mengalami nyeri terbanyak pada skala 3 (hurts even more) yaitu 12 orang (42,9\%).
Sedangkan, setelah melakukan kompres air hangat pada persalinan kala I fase aktif responden mengalami nyeri terbanyak pada skala 1 (hurts little bit) yaitu 16 orang $(57,2 \%)$.

Tabel 3. Hasil T-Test Dependen/ Paired T-Test

\begin{tabular}{lcccc}
\hline $\begin{array}{l}\text { Nyer i Kala I Fase } \\
\text { Aktif }\end{array}$ & N & Mean & SD & SE \\
\hline $\begin{array}{l}\text { Sebelum Kompres air } \\
\text { hangat }\end{array}$ & 28 & 3,82 & 0,819 & 0,155 \\
$\begin{array}{l}\text { Setelah kompres air } \\
\text { hangat }\end{array}$ & 28 & 1,54 & 0,693 & 0,131 \\
\hline
\end{tabular}


Jurnal Kebidanan Harapan Ibu Pekalongan

Tabel 3 menunjukkan jumlah responden sebanyak 28 orang. Hasil analisis statistik bahwa ibu bersalin kala I fase aktif mengalami penurunan (pengurangan) nyeri dari

Tabel 4. Tabel Uji Hipotesis nilai rerata sebelum kompres air hangat yaitu 3,82 menjadi nilai rerata setelah kompres air hangat yaitu 1,54 .

\begin{tabular}{ccccc}
\hline $\begin{array}{c}\text { Nyeri Kala I Fase } \\
\text { Aktif }\end{array}$ & N & Mean & SD & P-Value \\
\hline Sebelum - Setelah & 2 & & & \\
kompres air hangat & 8 & 2,286 & 0,659 & 0,0001 \\
\hline
\end{tabular}

Tabel 4. menunjukkan hasil analisis paired t-test yaitu $\mathrm{p}$-value 0,0001 dimana hasilnya $\mathrm{p}$ value $<$ 0,005 sehingga artinya ada perbedaan yang signifikan antara ibu bersalin yang memasuki persalinan kala I fase aktif sebelum diberikan kompres air hangat dengan ibu yang memasuki persalinan kala I fase aktif setelah diberikan kompres air hangat.

Penelitian ini didukung oleh penelitian Manurung S. et al (2013) bahwa ada pengaruh terapi kompres hangat terhadap penurunan dan pencegahan peningkatan skala nyeri persalinan setelah diterapi selama 20 menit terapi kompres hangat. Skala nyeri persalinan sebelum diterapi dan kelompok terapi kompres hangat, memiliki pengaruh yang sangat kuat dalam perubahan skala nyeri persalinan sesudah intervensi $(\mathrm{R}=0,9)$. Skala nyeri sesudah periode intervensi (kompres hangat) menurun sebesar 2,07 point. ${ }^{(12)}$

Selain mengurangi rasa nyeri selama persalinan, pemberian kompres air hangat pada ibu bersalin kala I fase aktif juga dapat berpengaruh secara simultan terhadap penurunan kecemasan. ${ }^{(13)}$ Hasil percobaan menghasilkan tingkat kenyamanan sebesar 3 pasien untuk kelompok kontrol, sementara kelompok yang mendapat perlakuan memperoleh tingkat kenyamanan sebesar 5 pasien. Hasil uji statistik Mann Whitney-U menghasilkan nilai Z-2,049 $<\mathrm{Z}$ tabel dengan Asymp sig : 0,04, yang menunjukkan bahwa pemberian kompres air hangat memberikan rasa nyaman dalam proses persalinan kala I fase aktif. $^{(13)}$

Kompres air hangat yang diberikan pada punggung bawah wanita di area tempat kepala janin menekan tulang belakang akan mengurangi nyeri. Panas pada kompres hangat akan meningkatkan sirkulasi ke area tersebut sehinga memperbaiki anoksia jaringan yang disebabkan oleh tekanan. Sumber panas dapat disalurkan melalui konduksi (botol air panas, bantalan pemanas listrik, lampu, kompres hangat kering dan lembab) atau konversi (Ultrasonografi, diatermi). Nyeri akibat spasme otot berespons baik terhadap panas, karena panas melebarkan pembuluh darah dan meningkatkan aliran darah lokal. Panas meredakan nyeri dengan menyingkirkan produk-produk inflamasi, seperti bradikinin, histamin dan prostaglandin yang akan menimbulkan nyeri lokal. Panas juga merangsang serat saraf 
Jurnal Kebidanan Harapan Ibu Pekalongan

yang menutup gerbang nyeri kemudian tranmisi implus nyeri ke medula spinalis dan otak dapat dihambat sehingga ini akan memberikan rasa nyaman saat ibu mengalami proses persalinan. ${ }^{(14),(15)}$

\section{Kesimpulan}

Berdasarkan data penelitian disimpulkan kompres air hangat lebih efektif dalam mengurangi rasa nyeri persalinan kala I. Ibu bersalin kala I fase aktif memiliki rasa sakit dengan rata-rata 3,28 lebih tinggi dibandingkan ibu setelah dilakukan kompres air hangat dengan rata-rata 1,54. Hasil analisis T-test dependen yaitu P-value 0,0001 ( $\mathrm{P}<0,05)$. Sehingga ada perbedaan yang signifikan nyeri pada ibu yang memasuki persalinan kala I fase aktif sebelum diberikan kompres air hangat dibandingkan setelah diberikan kompres air hangat. Penelitian ini sebagai dasar dan acuan bagi tenaga kesehatan untuk memberikan pengetahuan pada ibu bersalin tentang manfaat pemberian kompres air hangat sebagai alternatif utama dalam proses persalinan kala I fase aktif karena dapat mengurangi rasa nyeri. Selain itu kompres air hangat tidak mempunyai efek pada janin maupun ibu, lebih aman dan lebih murah.

\section{Daftar Pustaka}

[1] Rohani. Asuhan Kebidanan Pada Masa Persalinan. Jakarta: Salemba Medika, 2011.

[2] Manuaba. Pengantar Kuliah Obstetri. Jakarta: EGC, 2007.

[3] Maryunani A. Nyeri dalam persalinan tekhnik dan cara penanganannya. Jakarta: Trans Info Media, 2010.
[4] Putri Ika Damayanti dkk, Buku Ajar Asuhan Kebidanan Komprehensif pada Ibu Bersalin dan Bayi Baru Lahir. Yogyakarta: Deepublish, 2014.

[5] S. Abdul Rahman et,al., Penurunan Nyeri Persalinan dengan Kompres Hangat dan Massage Effleurage Decrease of Labor Pain with Warm Compress and Effleurage Massage, 2017.

[6] Tarsikah, H. Susanto and H.S.Sastramihardja, Penurunan Nyeri Persalinan Primigravida Kala I Fase Aktif Pascapenghirupan Aromaterapi Lavender, Maj. Kedokt. Bandung, vol.44, no.1, pp.19-26, 2012. doi: 10.15395/mkb.v44n1.210.

[7] Akbarzadeh, Marzieh, Azar Nematollahi, Mahnaz farahmand, and Sedigheh Amooee. The Effect of TwoStaged Warm Compress on the Pain Duration of First and Second Labor Stages and Apgar Score in Prim Gravida Women: A Randomized Clinical Trial. Journal of Caring Sciences 7(1): pp.2127, 2017.

[8] Varney. Buku Ajar Asuhan Kebidanan. Jakarta: EGC, 2008

[9] Manuaba. Ilmu Kebidanan, Penyakit Kandungan dan Keluarga Berencana untuk Pendidikan Bidan. Jakarta: EGC, 2000.

[10] Bobak. Buku Ajar Keperawatan Maternitas (Maternity Nursing). Jakarta: EGC, 2005.

[11] Notoatmodjo, Soekidjo. Pendidikan Dan Perilaku Kesehatan. Jakarta: Rineka Cipta, 2003. 
Jurnal Kebidanan Harapan Ibu Pekalongan

[12] Manurung, Suryani et.al. Pengaruh Teknik Kompres Hangat terhadap Perubahan Skala Nyeri Persalinan pada Klien Primigravida. Jurnal Health Quality 4(1), 2013. [Online]. https://d1wqtxts1 xzle7.cloudfr ont.net/55377738/7PENGARU H_TEKNIK_PEMBERIAN_K OMPRES_HANGAT TER $\bar{H} A$ DAP_PERUBAHAN_SKALA NYERI_PERSALINAN PA DA KLIEN PRIMIGRA VID A_2013.pdf?1514301139=\&re sponsecontentdisposition $=$ inlin e\%3B+filename\%DPengaruh_ Tehnik_Pemberian_Kom.

[13] Yani, Dian Puspita, and Uswatun Khasanah. Pengaruh Pemberian Kompres Air Hangat terhadap Rasa Nyaman dalam Proses Persalinan Kala I Fase Aktif. Jurnal Keperawatan: 1-5. 2012.

[14] Varney, H, dkk. Buku Ajar Asuhan Kebidanan. Jakarta: EGC, 2007.

[15] Perry \& Potter. Fundamental Keperawatan. Jakarta: EGC, 2005. 